\title{
PENGARUH PENGALAMAN MEREK DAN CITRA MEREK TERHADAP KEPUASAN KONSUMEN MENGGUNAKAN SHAMPO L'ORÉAL DI KOTA PALU
}

\author{
INTAN PERMATASARI \\ SYAMSUL BACHRI \\ PONIRIN \\ Program Studi S1 Manajemen Fakultas Ekonomi Universitas Tadulako \\ Email: iithaaaaaaaap@gmail.com
}

\begin{abstract}
This research aims to know and analyze: (1) To analyze the influence of brand experience and brand image simultaneously have a significant influence on consumer satisfaction using L'Oréal Shampoo in Palu City (2) To analyze the influence of brand experience partially have a significant influence on customer satisfaction L'Oréal Shampoo in Palu City and (3) To analyze the influence of brand image partially have a significant effect on consumer satisfaction using L'Oréal Shampoo in Palu City. The type of research used is quantitative (showing the relationship between variables). The population in the study were those who used L'Oréal Shampoo in Palu city twice in the last 3 months. Sampling technique in this study using purposive sampling, with the number of samples of 75 people. Data collection using questionnaires. The analytical method used multiple linear regression analysis using SPSS release 16. The results showed that (1) The influence of brand experience and brand image simultaneously influenced the consumer's satisfaction by using L'Oréal Shampoo in Palu City (2) brand partially influential to customer satisfaction using L'Oréal Shampoo in Palu City (3) There is influence of brand image by partially influential toward consumer's satisfaction using L'Oréal Shampoo in Palu City.
\end{abstract}

Keywords: brand experience, brand image, customer satisfaction

ABSTRAK
Penelitian ini bertujuan untuk mengetahui dan menganalisa: (1) Untuk menganalisis pengaruh pengalaman merek dan citra merek secara simultan berpengaruh signitifkan terhadap kepuasan konsumen menggunakan Shampo L'Oréal di Kota Palu (2) Untuk menganalisis pengaruh pengalaman merek secara parsial berpengaruh signitifkan terhadap kepuasan konsumen menggunakan Shampo L'Oréal di Kota Palu dan (3) Untuk menganalisis pengaruh citra merek secara parsial berpengaruh signitifkan terhadap kepuasan konsumen menggunakan Shampo L'Oréal di Kota Palu. Jenis penelitian yang digunakan adalah kuantitatif (menunjukan hubungan antar variabel). Populasi dalam penelitian adalah yang menggunakan Shampo L'Oréal di kota Palu sebanyak 2 kali dalam 3 bulan terakhir. Teknik penarikan sampel dalam penelitian ini menggunakan purposive sampling, dengan jumlah sampel sebanyak 75 orang. Pengambilan data menggunakan kuesioner. Metode analisis yang digunakan analisis regresi linear berganda dengan menggunakan aplikasi SPSS release 16. Hasil penelitian menunjukan bahwa (1) Terdapat pengaruh pengalaman merek dan citra merek secara simultan berpengaruh signitifkan terhadap kepuasan konsumen menggunakan Shampo L'Oréal di Kota Palu (2) Terdapat pengaruh pengalaman merek secara parsial berpengaruh signitifkan terhadap kepuasan konsumen menggunakan Shampo L'Oréal di Kota Palu (3) Terdapat pengaruh citra merek secara parsial berpengaruh signitifkan terhadap kepuasan konsumen menggunakan Shampo L'Oréal di Kota Palu.

Kata Kunci: pengalaman merek, citra merek, kepuasan pelanggan

\section{PENDAHULUAN}

Kosmetik menjadi suatu kebutuhan penting dalam kehidupan wanita sehari-hari dan digunakan terus menerus. Kosmetik membuat wanita menjadi lebih cantik, menambah kepercayaan diri dan menambah ketenangan. Fungsi lain kosmetik juga melindungi kulit dan rambut dari kerusakan karena sinar ultra violet (UV), polusi udara dan faktor-faktor lingkungan lainnya. Seiring dengan perkembangan jaman, masyarakat menjadi lebih modern dan semakin berkembang, sehingga 
penggunaan kosmetik juga semakin berkembang. Kosmetik bukan hanya digunakan pada wajah tetapi juga pada rambut, salah satu kosmetik perawatan rambut yaitu shampo.

Setiap wanita menganggap rambut sebagai mahkotanya, karena itu rambut mendapat perhatian yang begitu serius bagi para wanita. Para wanita ingin memiliki rambut yang sehat, indah, lembut dan sebagainya, yang pada akhirnya membuat para wanita lebih selektif di dalam memilih jenis shampo.

Saat ini ada banyak produk shampo yang beredar di pasaran, dari beberapa produk shampo tersebut salah satunya adalah perusahaan kecantikan terbesar di dunia asal Paris, L'Oréal. Perusahaan ini telah berdiri sejak tahun 1909 yang didirikan oleh Eugene Schuller dan masuk ke Indonesia sejak tahun 1970. Produk shampo dari L'Oréal yang dikeluarkan oleh PT. L'Oréal Indonesia merupakan kosmetik yang mengedepankan riset sebelum merancang produk. Pada tahun 2013 PT. L'Oréal Indonesia mengeluarkan produk shampo yang dirancang khusus untuk memenuhi kebutuhan preferensi orang indonesia.

Bermodalkan pengetahuan akan aspek-aspek shampo yang disukai oleh masyarakat Indonesia L'Oréal memposisikan diri menyasar segmen middle up. Tampilan botol dan iklan yang selalu terlihat elegan dan menggunakan bintang iklan perempuan dewasa seperti Dian Sastro Wardoyo mempresentasikan bahwa L'Oréal cocok untuk wanita sukses dan remaja perempuan yang ingin berkilau kehidupannya seperti Dian Sastro.

Kini dengan adanya teknologi yang sangat maju konsumen dapat mencari brand apa saja yang mereka inginkan melalui web Youtube maupun televisi. konsumen juga bisa melakukan review dengan menggunakan internet seberapa besar kepuasan konsumen menggunakan produk tertentu sehingga dapat memberikan informasi yang update kepada calon konsumen sebelum memutuskan membeli. Kondisi ini memberikan pengaruh terhadap persepsi atau penerimaan publik terhadap brand yang diperbincangkan. Penelitian ini bertujuan untuk meneliti bagaimana kaum wanita di Kota Palu menilai, memandang, menerima, dan memberikan persepsi terhadap suatu brand tertentu, khusunya brand kosmetik yang sangat dekat dengan kehidupan wanita.

Berdasarkan fenomena perubahan perilaku tersebut, Penelitian ini akan mengkaji apakah pengalaman merek dan citra merek berpengaruh terhadap kepuasan konsumen menggunakan Shampo L'Oréal di Kota Palu. Penelitian ini berfokus pada brand image karena adanya perubahan sikap konsumen terhadap brand L'Oréal yang terlihat sangat jelas. Berawal dari kemunculan review produk, hingga konsumen memutuskan melalukan pembelian. Adapun tujuan yang ingin dicapai dalam penelitian ini adalah:

1. Untuk menganalisis pengaruh pengalaman merek dan citra merek terhadap kepuasan konsumen menggunakan Shampo L'Oréal di Kota Palu.

2. Untuk menganalisis pengaruh pengalaman merek terhadap kepuasan konsumen menggunakan Shampo L'Oréal di Kota Palu.

3. Untuk menganalisis pengaruh citra merek terhadap kepuasan konsumen menggunakan Shampo L'Oréal di Kota Palu.

\section{KAJIAN LITERATURE DAN PENGEMBANGAN HIPOTESIS}

\section{Pengalaman Merek}

Menurut Brakus et al. (2009) brand experience didefinisikan sebagai sensasi, perasaan, kognisi dan tanggapan konsumen yang ditimbulkan oleh merek,terkait rangsangan yang ditimbulkan oleh desain merek, identitas merek, komunikasi pemasaran, orang dan lingkungan merek tersebut dipasarkan. Untuk dapat mendefinisikan lebih jauh mengenai brand experience memulai penelitian dengan melihat sudut pandang konsumen dengan menguji pengalaman konsumen itu sendiri dan bagaimana pengalaman itu menghasilkan pendapat sikap, dan aspek lainnya dari perilaku konsumen.Terdapat empat dimensi pengalaman merek (brand experience): 
1. Sensorik

Menciptakan pengalaman melalui penglihatan, suara, sentuhan, bau, dan rasa.

2. Afeksi

Pendekatan perasaan dengan mempengaruhi suasana hati, perasaan, dan emosi.

3. Perilaku

Menciptakan pengalaman secara fisik, pola perilaku, dan gaya hidup.

4. Intelektual

Menciptakan pengalaman yang mendorong konsumen terlibat dalam pemikiran seksama mengenai keberadaan suatu merek.

\section{Definisi Citra Merek (Brand Image)}

Citra merek menurut Kotler \& Keller (2009) merupakan seperangkat keyakinan, ide, dan kesan yang dimiliki oleh seseorang terhadap suatu merek. Konsumen yang memiliki citra yang positif terhadap suatu merek, akan lebih memungkinkan untuk melakukan pembelian. Telah dikemukakan bahwa citra merek tidak terdapat dalam fitur, teknologi atau jenis produk itu sendiri, citra timbul karena iklan, promosi atau penggunaannya. Melalui citra merek, konsumen dapat mengenali produk, mengevaluasi kualitas, mengurangi risiko pembelian, dan memperoleh pengalaman tertentu serta mendapatkan kepuasan tertentu dari suatu produk.

Menurut Aaker \& Biel (2009) citra merek terdiri atas tiga komponen:

1. Citra pembuat (Corporate Image) yaitu sekumpulan asosiasi yang dipersepsikan konsumen terhadap perusahaan yang membuat suatu produk dan jasa. Citra pembuat meliputi: popularitas, kredibilitas dan jaringan perusahaan.

2. Citra pemakai (user image) yaitu sekumpulan asosiasi yang dipersepsikan konsumen terhadap pemakai yang menggunakan barang atau jasa, meliputi pemakai itu sendiri, gaya hidup atau kepribadian dan status sosial, citra pembuat meliputi: pemakai itu sendiri dan status dan status sosialnya.

3. Citra produk (product image) yaitu sekumpulan asosiasi yang dipersepsikan konsumen terhadap suatu produk, yang meliputi atribut produk tersebut, manfaat bagi konsumen penggunanya, serta jaminan, citra pembuat meliputi: atribut dari produk, manfaat bagi konsumen, serta jaminannya

\section{Pengertian Kepuasan Pelanggan}

Menurut Kotler \& Keller (2009) kepuasan adalah perasaan senang atau kecewa seseorang yang timbul karena membandingkan kinerja yang dipersepsikan produk atau hasil terhadap ekspektasi mereka. Kepuasan tercapai ketika kualitas memenuh dan melebihi harapan, keinginan dan kebutuhan konsumen. Sebaliknya, bila kualitas tidak memenuhi dan melebihi harapan, keinginan dan kebutuhan konsumen maka kepuasan tidak tercapai. Konsumen yang tidak puas terhadap barang atau jasa yang dikonsumsinya akan mencari perusahaan lain yang mampu menyediakan kebutuhannya.

\section{Hubungan antar Variabel}

a. Hubungan Antara Pengalaman Merek dan Citra Merek Terhadap Kepuasan Konsumen

Menurut Kusuma (2014) brand experience memiliki pengaruh yang signifikan terhadap brand satisfaction, Semakin baik pengalaman merek yang maka semakin baik pula kepuasaan merek di mata konsumen. Sedangkan Menurut Suharyono dan Kusumawati (2014) hubungan citra merek dengan kepuasan konsumen memiliki pengaruh yang positif. merek merupakan image atau sesuatu melekat di benak konsumen. Semakin baik persepsi di benak konsumen terhadap citra merek perusahaan maka kepuasan konsumen juga akan semakin tinggi. Pengalaman merek dan citra merek memiliki pengaruh yang signitifkan terhadap kepuasan konsumen. 
b. Hubungan Antara Pengalaman Merek terhadap Kepuasan Pelanggan

Menurut Tsai \& Ho (2015) pengalaman merek memiliki efek langsung dan positif terhadap kepuasan pelanggan, yang berarti semakin banyak pengalaman yang dimiliki pelanggan dengan merek, semakin besar preferensi merek mereka akan berkembang.

c. Hubungan Antara Citra Merek terhadap Kepuasan Pelanggan

Menurut Yana et al. (2015) menyatakan bahwa hubungan citra merek dengan kepuasan konsumen memiliki pengaruh yang positif. kepuasan pelanggan merupakan suatu tingkatan dimana konsumen merasa senang atau kecewa terhadap suatu produk.Jadi citra merek yang positif akan menyebabkan terjadinya kepuasan pada pelanggannya.

\section{Hipotesis}

Berdasarkan perumusan masalah, tujuan penelitian, dan tinjauan teoretis seperti yang telah diuraikan sebelumnya, Menunjukan hipotesis penelitian sebagai berikut:

1. Pengalaman merek dan citra merek secara simultan berpengaruh signitifkan terhadap kepuasan konsumen menggunakan Shampo L'Oréal di Kota Palu.

2. Pengalaman merek secara parsial berpengaruh signitifkan terhadap kepuasan konsumen menggunakan Shampo L'Oréal di Kota Palu.

3. Citra merek secara parsial berpengaruh signitifkan terhadap kepuasan konsumen menggunakan Shampo L'Oréal di Kota Palu.

\section{METODE PENELITIAN}

Penelitian ini menggunakan metode penelitian survei yaitu suatu penelitian yang mengambil sampel dari suatu populasi dengan menggunakan kuesioner sebagai instrumen pengumpulan data. Jenis penelitian ini adalah penelitian deskriptif dan kausal, menurut Sugiyono (2009) penelitian deskriptif adalah penelitian yang menggambarkan, menjelaskan variabel-variabel penelitian atau menganalisis suatu hasil penelitian. Menurut Malhotra \& Peterson (2006) kausal bertujuan untuk mencari hubungan sebab-akibat antara variabel independen terhadap variabel dependen. Deskriptif kausal adalah menganalisis hubungan sebab-akibat, dalam penilitian ini yang ingin dianalisis adalah hubungan sebab akibat antar variabel independen (variabel bebas) yaitu Pengalaman Merek dan Citra Merek terhadap variabel dependen (variabel terikat) yaitu kepuasan konsumen. Penelitian ini dilakukan di Toko Mutiara yang berlokasi dijalan Dr. Soetomo dan jalan Gajahmada, Penelitian membutuhkan waktu selama dua bulan untuk penyelesaiannya.

Populasi dalam penelitian ini adalah konsumen yang telah melakukan pembelian dan menggunakan shampo L'Oréal sedikitnya dua kali selama tiga bulan terakhir dan berdomisili di Kota Palu. Metode pengambilan sampel yang digunakan dalam penelitian ini adalah non-probability sampling yaitu dengan menggunakan teknik purposive sampling. Untuk menemukan jumlah sampel dalam penelitian ini merujuk pada teori Roscoe adalah jumlah anggota sampel setiap kategori minimal 10 kali dari jumlah variabel yang diteliti (Sugiyono, 2013). Jumlah variabel penelitian ini adalah 3 variabel yang terdiri dari variabel independen (pengalaman merek dan citra merek) dan variabel dependen (kepuasan pelanggan). Berdasarkan dengan teori tersebut maka jumlah populasi dalam $25 \times$ ( 2 independen +1 dependen) atau $25 \times(2+1)=25 \times 3=75$ responden.

Adapun metode analisis data dalam penelitian ini, yaitu:

1. Pengujian Instrumen

1) uji validitas , Menurut Sugiyono (2013) adalah sejauh mana kehandalan sebuah alat ukur dalam mengukur apa yang diukur. Instrumen yang valid berarti alat ukur yang digunakan untuk mendapatkan data. Syarat minimum untuk dianggap memenuhi syarat adalah $r=0,3$. Jadi, kolerasi antara butir dengan skor total kurang dari 0,3 maka butir dalam instrument tersebut 
dinyatakan tidak valid. Sebaliknya, jika skor total positif dan lebih besar dari 0,3 (r>0,3) maka instrument tersebut dinyatakan valid.

2) Uji Realibilitas, Sebuah faktor dinyatakan reliabel jika koefisien alpha lebih besar dari 0,6 (Supramono \& Johny, 2005).

2. Uji Asumsi Klasik

1) Uji normalitas, digunakan untuk mengetahui apakah populasi data berdistribusi normal atau tidak. Uji normalitas dalam penelitian ini akan dilakukan dengan menggunakan OneSample Kolmogorov-Smirnovtest dengan menggunakan taraf signifikansi 0,05. Data dinyatakan berdistribusi normal jika signifikansi lebih besar dari 5\% atau 0,05 (Ghozali, 2006).

2) Uji Multikolonieritas, bertujuan untuk menguji apakah model regresi ditemukan adanya korelasi antar variabel bebas (Independen). Ujiasumsi klasik multikolinieritas hanya dapat dilakukan jika terdapat lebih dari satu variabelindependen dalam model regresi. Model regresi yang baik seharusnya tidak terjadi korelasi di antara variabel independen. Uji multikolinieritas dalam penelitian dilakukan dengan melihat nilai Variance Inflation Factor (Ghozali, 2006).

3) Uji heteroskedastisitas, Menurut Ghozali (2013) yaitu Jika p value $>0,05$ tidak signifikan berarti tidak terjadi heteroskedastisitas artinya model regresi lolos uji heteroskedastisitas. Model regresi yang baik adalah yang homokedastisitas atau tidak terjadi heterokedastisitas. Kebanyakan data crossection mengandung situasi heterokedastisitas karena data ini menghimpun data yang mewakili berbagai ukuran (kecil, sedang dan besar).

4) Uji linearitas, Uji linearitas dilakukan dengan menggunakan analisi variansi terhadap garis regresi yang nantinya akan diperoleh harga Fhitung. Harga $f$ yang diperoleh kemudian dikonsultankan dengan harga Ftabel pada taraf signitifkan 5\%. Kriteria apabila Fhitung lebih kecil atau sama dengan Ftabel pada taraf signitifkan 5\% maka antara variabel bebas dikatakan linier. Sebaliknya, apabila Fhitung lebih besar daripada Ftabel maka hubungan variabel bebas terhadap variabel terikat tidak linier (Nurgiyantoro \& Marzuki, 2012).

3. Regresi Linear Berganda

Regresi Linear Berganda menggunakan bantuan komputer program SPSS Release 16.0. Bentuk formulasi alat analisis statistik Regresi Linear Berganda secara matematis dapat dijabarkan sebagai berikut (Rangkuti, 2007).

$$
Y=a+b_{1} X_{1}+b_{2} X_{2}+\ldots \ldots+b_{a} X_{a}
$$

Dimana:

$\mathrm{Y}=$ Variabel dependen

a $\quad=$ konstanta

$\mathrm{b}_{1} \mathrm{~b}_{\mathrm{n}} \quad=$ koefisien regresi

$\mathrm{X}_{1}-\mathrm{X}_{\mathrm{n}}=$ variabel independen

Bila informasi matematis regresi linear berganda tersebut diaplikasikan dalam penelitian ini, maka akan diperoleh bentuk persamaan sebagai berikut:

Keterangan:

$$
Y=a+b_{1} X_{1}+b_{2} X_{2}+\varepsilon
$$




$\begin{array}{ll}\mathrm{A} & =\text { Konstanta } \\ \mathrm{Y} & =\text { Kepuasan Konsumen } \\ \mathrm{b}_{1} \text { dan } \mathrm{b}_{2} & =\text { Koefisien Regresi masing-masing Variabel } \\ \mathrm{X}_{1} & =\text { Pengalaman Merek } \\ \mathrm{X}_{2} & =\text { Citra Merek } \\ \varepsilon & =\text { Error }\end{array}$

\section{HASIL DAN PEMBAHASAN}

\section{Hasil Uji Validitas dan Realibilitas}

Instrumen penelitian diuji validitas dan reliabilitasnya guna mengetahui apakah alat ukur yang digunakan cocok untuk penelitian tersebut sehingga dapat memberikan hasil maksimal atas jawaban responden serta sesuai dengan tujuan penelitian yang diharapkan. Jumlah responden yang digunakan sebanyak 26 responden. Adapun hasilnya disajikan dalam tabel 1 berikut:

\section{Tabel 1}

Validitas Instrumen Penelitian

\begin{tabular}{|c|c|c|c|}
\hline Variabel & Item & Total Correlation & Keterangan \\
\hline \multirow{5}{*}{ Pengalaman Merek $\left(\mathrm{X}_{1}\right)$} & X1.1 & 0,372 & Valid \\
\hline & $\mathrm{X} 1.2$ & 0,551 & Valid \\
\hline & $\mathrm{X} 1.3$ & 0,628 & Valid \\
\hline & $\mathrm{X} 1.4$ & 0,385 & Valid \\
\hline & $\mathrm{X} 1.5$ & 0,624 & Valid \\
\hline \multirow{8}{*}{ Citra Merek $\left(\mathrm{X}_{2}\right)$} & $X 2.1$ & 0,361 & Valid \\
\hline & $X 2.2$ & 0.373 & Valid \\
\hline & $X 2.3$ & 0.630 & Valid \\
\hline & $X 2.4$ & 0,530 & Valid \\
\hline & $X 2.5$ & 0,673 & Valid \\
\hline & $X 2.6$ & 0,679 & Valid \\
\hline & $X 2.7$ & 0,496 & Valid \\
\hline & $X 2.8$ & 0,472 & Valid \\
\hline \multirow{3}{*}{ Kepuasan Pelanggan (Y) } & $Y 1$ & 0,776 & Valid \\
\hline & $Y 2$ & 0.932 & Valid \\
\hline & $Y 3$ & 0,932 & Valid \\
\hline
\end{tabular}

Sumber: Data diolah Tahun 2018

Berdasarkan hasil uji validitas diperoleh bahwa seluruh variabel memiliki total correlation lebih besar dari 0,3 sehingga berdasarkan syarat minimum validitas lebih besar dari 0,3 maka seluruh variabel Pengalaman Merek $\left(\mathrm{X}_{1}\right)$, Citra Merek $\left(\mathrm{X}_{2}\right)$, Kepuasan Pelanggan (Y) dinyatakan valid dan dapat digunakan dalam penelitian.

Tabel 2

Reliabilitas Instrumen Penelitian

\begin{tabular}{|lcc|}
\hline \multicolumn{1}{|c|}{ Variabel } & Cronbach Alpha & Keterangan \\
\hline Pengalaman Merek $\left(\mathbf{X}_{\mathbf{1}}\right)$ & 0,738 & Reliabel \\
\hline Citra Merek $\left(\mathbf{X}_{\mathbf{2}}\right)$ & 0,807 & Reliabel \\
\hline Kepuasan Konsumen $(\mathbf{Y})$ & 0,937 & Reliabel \\
\hline
\end{tabular}

Sumber: Data diolah Tahun 2018 
Berdasarkan hasil uji reliabilitas diperoleh bahwa seluruh variabel memiliki koefisien Cronbach Alpha (a) lebih besar dari 0,60 sehingga berdasarkan syarat minimum reliabilitas lebih besar dari 0,60 maka seluruh variabel Pengalaman Merek $\left(\mathrm{X}_{1}\right)$, Citra Merek $\left(\mathrm{X}_{2}\right)$, Kepuasan Pelanggan (Y) dinyatakan valid dan dapat digunakan dalam penelitian.

\section{Hasil Uji Analisis Regresi Linear Berganda}

Penelitian ini menggunakan analisis regresi linear berganda dengan tujuan untuk menguji pengaruh pengalaman merek dan citra merek terhadap kepuasan pelanggan menggunakan bantuan komputer program SPSS Release 16.0. Bentuk formulasi alat analisis statistik Regresi Linear Berganda secara matematis dapat dijabarkan. Untuk lebih jelasnya hasil analisis regresi linear berganda dapat dilihat pada tabel 3 berikut:

Tabel 3

Hasil Uji Analisis Regresi Linear Berganda

\begin{tabular}{|c|c|c|c|c|c|c|}
\hline \multicolumn{7}{|c|}{ Dependen Variabel Y = Kepuasan Konsumen } \\
\hline & \multirow{2}{*}{$\begin{array}{l}\text { Variabel } \\
\text { Independen }\end{array}$} & \multicolumn{2}{|c|}{$\begin{array}{c}\text { Unstandardized } \\
\text { Coefficients }\end{array}$} & \multirow{2}{*}{$\begin{array}{c}\begin{array}{c}\text { Standardized } \\
\text { Coefficients }\end{array} \\
\text { Beta }\end{array}$} & \multirow[b]{2}{*}{$\mathbf{t}$} & \multirow[b]{2}{*}{ Sig. } \\
\hline & & B & $\begin{array}{c}\text { Std. } \\
\text { Error }\end{array}$ & & & \\
\hline \multirow[b]{3}{*}{1} & (Constant) & 0,574 & 0,431 & & 1,330 & 0,188 \\
\hline & $\mathrm{X} 1$ & 0,331 & 0,103 & 0,310 & 3,223 & 0,002 \\
\hline & $\mathrm{X} 2$ & 0,639 & 0,123 & 0,501 & 5,198 & 0,000 \\
\hline \multicolumn{2}{|c|}{ Multiple R } & 0,710 & \multicolumn{3}{|c|}{ Sig F = 0,000 } & \\
\hline \multicolumn{2}{|c|}{ Adjusted R Square = } & 0,491 & $=\mathbf{0 , 0}$ & tingkat keperc & $\operatorname{aan} 95 \%$ & \\
\hline
\end{tabular}

Sumber: Data diolah Tahun 2018

Berdasarkan tabel 3 di atas, dapat di tulis dalam bentuk persamaan regresi linear berganda. Untuk lebih jelasnya bentuk persamaan tersebut dapat dilihat sebagai berikut:

$Y=0,574+0,331 X_{1}+0,639 X_{2}+\varepsilon$

Berdasarkan penjabaran di atas menunjukkan bahwa, variabel independen yang dianalisis yaitu variabel $\left(\mathrm{X}_{1}\right.$ dan $\mathrm{X}_{2}$ ) memberikan pengaruh positif terhadap variabel dependen (Y), yaitu kepuasan konsumen menggunakan shampo L'Oréal di Kota Palu. Untuk lebih jelasnya penjelasan bentuk persamaan tersebut dapat dilihat berikut ini:

1. Nilai Konstanta sebesar 0,574 memberikan arti jika variabel (pengalaman merek, citra merek) bernilai 0, maka variabel dependen (kepuasan konsumen menggunakan shampo L'Oréal di Kota Palu) nilainya sebesar 0,574 . Setiap ada kenaikan pada variabel independen sebesar satu satuan maka akan meningkatkan variabel dependen sebesar nilai koefisiensi beta masing-masing variabel independen dikalikan dengan besarnya kenaikan yang terjadi.

2. Koefisien regresi dimensi dimensi Pengalaman merek $\left(\mathrm{X}_{1}\right)$ sebesar 0,331 ; artinya bahwa pengaruh variabel pengalaman merek terhadap kepuasan konsumen menggunakan shampo L'Oréal di Kota Palu adalah bersifat positif dan jika skor variabel pengalaman merek meningkat maka kepuasan konsumen menggunakan shampo L'Oréal di Kota Palu juga akan meningkat.

3. Koefisien regresi dimensi Citra Merek $\left(\mathrm{X}_{2}\right)$ 0,639; artinya bahwa pengaruh variabel citra merek terhadap kepuasan konsumen menggunakan shampo L'Oréal di Kota Palu adalah bersifat positif dan jika skor variabel citra merek meningkat maka kepuasan konsumen menggunakan shampo L'Oréal di Kota Palu juga akan meningkat. 


\section{Hasil Pengujian Hipotesis Hasil Pengujian Hipotesis Secara Simultan (Uji F)}

\section{Tabel 4 \\ Hasil Uji F (Simultan)}

\begin{tabular}{|l|ccccc|}
\multicolumn{1}{|c|}{ Model } & $\begin{array}{c}\text { Sum of } \\
\text { Squares }\end{array}$ & Df & $\begin{array}{c}\text { Mean } \\
\text { Square }\end{array}$ & $\boldsymbol{F}$ & Sig. \\
\hline Regression & 9,193 & 2 & 4,596 & 36,674 & $0,000^{\text {a }}$ \\
\hline Residual & 9,024 & 72 & 0,125 & & \\
\hline Total & 18,216 & 74 & & & \\
\hline
\end{tabular}

Sumber: Data diolah Tahun 2018

Berdasarkan tabel 4 di atas diperoleh Sig.F yaitu 0,000, artinya nilai tersebut lebih kecil dibandingkan dengan nilai yang disyaratkan yaitu $\alpha=0,05$ atau dengan tingkat kepercayaan $95 \%$. Maka dapat dinyatakan bahwa hipotesis pertama $\left(\mathrm{H}_{1}\right)$ yang menyatakan bahwa pengalaman merek dan citra merek secara serempak berpengaruh signifikan terhadap kepuasan konsumen menggunakan shampo L'Oréal di Kota Palu terbukti atau diterima.

\section{Hasil Pengujian Hipotesis Secara parsial (Uji t)}

Hasil Uji t adalah untuk mengetahui apakah masing-masing variabel bebas pengalaman merek $\left(\mathrm{X}_{1}\right)$ dan citra merek $\left(\mathrm{X}_{2}\right)$ secara parsial berpengaruh terhadap kepuasan pelanggan $(\mathrm{Y})$. Adapun hasil pengujian secara parsial untuk setiap variabel independen terhadap variabel dependen dapat dilihat dari penjelasan berikut:

1. Variabel Pengalaman merek

Hipotesis kedua $\left(\mathrm{H}_{2}\right)$ dalam penelitian ini menyatakan bahwa pengalaman merek secara parsial berpengaruh signifikan terhadap kepuasan konsumen menggunakan shampo L'Oréal di Kota Palu. Tabel 3 di atas menunjukkan bahwa pengalaman produk $\left(\mathrm{X}_{1}\right)$ memiliki nilai signifikan sebesar 0,00 . Artinya nilai tersebut lebih kecil dari taraf yang disyaratkan yaitu $\alpha=0,05$, maka dapat disimpulkan bahwa hipotesis kedua dinyatakan diterima, dimana secara parsial pengalaman merek berpengaruh signifikan terhadap kepuasan konsumen menggunakan shampo L'Oréal di Kota Palu.

2. Variabel Citra Merek

Hipotesis ketiga $\left(\mathrm{H}_{3}\right)$ menyatakan bahwa citra merek secara parsial berpengaruh signifikan terhadap kepuasan konsumen menggunakan shampo L’Oréal di Kota Palu. Berdasarkan Tabel di atas menunjukkan bahwa citra merek $\left(\mathrm{X}_{2}\right)$ memiliki nilai signifikan sebesar 0,00 . Artinya nilai tersebut lebih kecil dari taraf yang disyaratkan yaitu $\alpha=0,05$, dengan demikian maka hipotesis ketiga yang menyatakan bahwa secara parsial citra merek berpengaruh signifikan terhadap kepuasan konsumen menggunakan shampo L'Oréal di Kota Palu dinyatakan diterima.

\section{PEMBAHASAN}

\section{Hasil Analisis Secara Simultan}

Berdasarkan hasil pengujian serta analisis yang telah dilakukan pada penelitian ini membuktikan bahwa pengalaman merek dan citra merek secara simultan berpengaruh signifikan terhadap kepuasan konsumen menggunakan shampo L'Oréal di Kota Palu. Berdasarkan tabel rekapitulasi regresi linear berganda dapat dilihat pengaruh hasil uji determinasi Adjusted $R$ Square sebesar 0,491. Nilai tersebut dapat diartikan bahwa seluruh variabel bebas yakni pengalaman produk dan citra merek yang terdiri daripengalaman merek, dan citra merekmempunyai konstribusi secara bersama-sama sebesar 49,1\% terhadap variabel terikat yaitu terhadap kepuasan konsumen menggunakan shampo L'Oréal di Kota Palu. Sedangkan sisanya (100\% - 49,1\%) yaitu 50,9\% dipengaruhi oleh variabel lain yang tidak 
diteliti. Adapun tingkat keeratan hubungan antara variabel bebas yaitu pengalaman merek dan citra merek terhadap variabel terikat yaitu terhadap kepuasan konsumen menggunakan shampo L'Oréal di Kota Palu. dapat dilihat dari nilai Multiple R sebesar 0,710 atau $71 \%$. hasil tersebut menunjukkan bahwa secara keseluruhan variabel bebas berhubungan cukup erat terhadap variabel terikat.

\section{Hasil Analisis Secara Parsial \\ Pengalaman Merek}

Penelitian ini menunjukkan bahwa untuk meningkatkan pengalaman merek yang baik maka perusahaan harus mampu menanamkan kesan yang kuat pengenai merek/produk yang dipasarkan. Perusahaan atau pemilik merek sebaiknya mengkomunikasikan produk/mereknya dengan pesan-pesan yang mampu menyakinkan kekuatan mereknya, dan yang tidak kalah penting adalah memilih media yang tepat sehingga mampu memperkuat kesan atas produk/merek. Pada penelitian ini diperoleh informasi bahwa pemilik atau pemasar shampo L'Oréal di Kota Palu belum cukup mampu menghasilkan ikatan emosi yang kuat antara shampo ini dengan penggunanya. Pemasar shampo L'Oréal perlu meningkatkan upaya ini untuk meningkatkan pengalaman merek konsumen yang lebih tinggi sehingga pada gilirannya mampu meningkatkan kepuasan pelanggan.

Lebih lanjut, hasil penelitian ini sejalan dngan penelitian sebelumnya yang dilakukan oleh Tsai \& Ho (2015) yang menemukan bahwa pengalaman merek memiliki efek langsung dan positif terhadap kepuasan pelanggan, yang berarti semakin baik pengalaman yang dirasakan pelanggan dengan suatu merek, maka akan semakin besar preferensi merek mereka akan berkembang yang tentunya akan meningkatkan kepuasan mereka.

\section{Citra Merek}

Berdasarkan hasil penelitian ini, indikator-indikator yang digunakan untuk mengukur citra merek berpengaruh signifikan kepuasan konsumen menggunakan shampo L'Oréal di Kota Palu. Hal ini menunjukkan bahwa semakin baik image shampo L'Oréal dimata konsumen maka citra dapat mempengaruhi kepuasan konsumen menggunakan shampo L'Oréal di Kota Palu.

Hasil penelitian ini sejalan dengan penelitian sebelumnya yang dilakukan Yana et al. (2015) menunjukkan bahwa citra merek memiliki pengaruh positif signifikan terhadap kepuasan pelanggan. Kepuasan pelanggan merupakan suatu tingkatan dimana konsumen merasa senang atau kecewa terhadap suatu produk. Konsumen akan merasa puas akan suatu barang apabila dia mempunyai persepsi baik terhadap suatu produk, atau dengan kata lain kepuasan terbentuk karena produk yang dikonsumsi memenuhi harapan konsumen.

\section{KESIMPULAN DAN SARAN}

\section{Kesimpulan}

Berdasarkan hasil penelitian yang telah dijabarkan, maka diperoleh kesimpulan mengenai pengaruh pengalaman merek dan citra merek terhadap kepuasan konsumen menggunakan Shampo L'Oréal di Kota Palu.

1. Pengalaman merek dan citra merek secara simultan berpengaruh signifikan terhadap kepuasan konsumen menggunakan Shampo L'Oréal di Kota Palu.

2. Pengalaman merek secara parsial berpengaruh positif dan signifikan terhadap kepuasan konsumen menggunakan Shampo L'Oréal di Kota Palu.

3. Citra merek berpengaruh secara parsial berpengaruh positif dan signifikan terhadap kepuasan konsumen menggunakan Shampo L'Oréal di Kota Palu.

\section{Saran}

Berdasarkan kesimpulan yang telah diuraikan sebelumnya, maka saran-saran yang tepat menyangkut kegunaan penelitian ini dapat diuraikan sebagai berikut: 
1. Mengingat kelemahan shampo ini dalam membentuk ikatan emosi yang kuat sehinga merek ini menjadi merek yang tidak tergantikan, maka perusahaan sebaiknya melakukan upaya pemasaran terintegrasi untuk meningkatkan pengalaman merek. Dengan program ini diharapkan akan mampu meningkatkan ikatan emosional yang kuat antara merek L'Oreal dengan penggunannya, yang pada akhirnya akan meningkatka kepuasan pengguna/konsumen.

2. Diharapkan adanya inovasi dari komposisi shampo L'Oreal yang bisa meningkatkan manfaat dan fungsinya sehingga cocok bagi semua kalangan dan aman digunakan sehari-hari memberikan pengalaman yang lebih baik lagi agar lebih memberikan kepuasan yang lebih tinggi sehingga mencegah konsumen beralih ke produk pesaing lainnya.

3. Dengan perkembangan dunia yang cepat, maka kebutuhan pengguna dapat berubah dengan cepat. Manajemen hendaknya cepat tanggap dalam merespon keinginan pengguna produk shampo L'Oréal.

4. Kepada peneliti selanjutnya disarankan untuk mempertimbangkan penambahan variabel lain selain yang telah digunakan dalam penelitian ini, sehingga lebih dapat mengukur sebab-sebab yang mempengaruhi kepuasan konsumen menggunakan shampo L'Oréal. Penelitian berikutnya juga dapat mempertimbangkan untuk menggunakan ukuran sampel yang lebih besar dari jumlah sampel yang digunakan pada penelitian ini sehingga keakuratan hasil penelitian akan lebih baik.

\section{REFERENSI}

Aaker, D., \& Biel, A. L. (2009). Brand Equity And Advertising. Adversiting Role in Building Strong Brands. Hillsdale: Lawrence Erlbaum Associates Inc.

Brakus, J. J., Schmitt, B. H., \& Zarantonelo, L. (2009). Brand Experience: What is it? How is it Meassured? Does it Affect Loyalty? Journal of Marketing, 73(2), 52-68.

Ghozali. (2006). Uji Normalitas Regresi dengan SPSS. Semarang: Universitas Ponegoro.

Ghozali, I. (2013). Aplikasi Analisis Multivariate dengan Program SPSS (Ketujuh). Semarang: Badan Penerbit Universitas Diponegoro.

Kotler, P., \& Keller, K. L. (2009). Manajemen Pemasaran Jilid 1 (13th ed.). Jakarta: Erlangga.

Kusuma, Y. S. (2014). Pengaruh Brand Experience terhadap Brand Loyalty melalui Brand Satisfaction dan Brand Trust Harley Davidson di Surabaya. Jurnal Manajemen Pemasaran Petra, 2(1), 111.

Malhotra, N. K., \& Peterson, M. (2006). Basic Marketing Research (Second). New Jersey: Pearson Education Inc.

Nurgiyantoro, B. G., \& Marzuki. (2012). Statistik Terapan Untuk Penelitian Ilmu-Ilmu Sosial. Yogyakarta: Gajah Mada Universitas Press.

Rangkuti, F. (2007). Riset Pemasaran, Cetakan VIII. Jakarta: PT. Gramedia Pustaka Utama.

Sugiyono. (2009). Metode Penelitian Kuantitatif, Kualitatif dan R\&D. Bandung: Alfabeta.

Sugiyono. (2013). Metode Penelitian Bisnis (Pendekatan Kuantitatif, Kualitatif dan R\&D). Bandung: Alfabeta.

Suharyono D.K., dan Kusumawati, A. (2014). Pengaruh Citra Merek Dan Kualitas Produk Terhadap Kepuasan Dan Loyalitas. Jurnal Administrasi Bisnis (JAB), Vol. 14, Hlm. 3-4.

Tsai, H.-C. C. Y.-C., \& Ho, K.-C. (2015). A Study of the Relationship among Brand Experiece, SelfConcept Congruence, Customer Satisfaction, and Brand Preference. Contemporary Management Research, 11(2), 97-116.

Yana, R. D., Suharyono, \& Abdillah, Y. (2015). Pengaruh Citra Merek terhadap Kepuasan Pelanggan dan Loyalitas Pelanggan (Survei Pada Konsumen Produk Busana Muslim Dian Pelangi Di Malaysia). Jurnal Administrasi Bisnis (JAB), 21(1) 